\title{
Obstrução esofágica em potro por ingestão de concetrado
}

Maísa Alves Batista de Souza, lara Nóbrega Macedo, Walter Henrique Cruz Pequeno, Alexandra Melo Oliveira, Lucas Barbosa

Serafim, Igor Mariz Dantas, Karla Campos Malta, Isabella de Oliveira Barros"

Universidade Federal da Paraíba (UFPB), Areia, PB, Brasil

*Autor correspondente

e-mail: doutorabella@hotmail.com

\section{Resumo}

Toda obstrução esofágica é uma emergência na clínica médica de equídeos; isso ocorre devido ao aumento de pressão exercida sobre a mucosa esofágica causada pelo material obstrutivo, acarretando extensa lesão tecidual com consequente formação de tecido fibroso, estenose, e perfuração esofágica. 0 propósito desse relato é descrever um caso de obstrução esofágica em um potro após ingestão de concentrado. Deu entrada no Hospital Veterinário da UFPB um potro de 3 anos de idade, sem raça definida, com queixa de regurgitação alimentar e episódios de descarga nasal com secreção mucopurulenta. Segundo o proprietário, o animal era criado de forma extensiva com pouca disponibilidade de água, só recebia concentrado aos finais de semana e há três dias encontrava-se sem se alimentar. Durante o exame clínico, após sedação com xilazina (1mg/ $\mathrm{kg}$, endovenoso), realizou-se gastroscopia, porém, devido à presença de grande quantidade de secreção, não foi possível completa visualização do esôfago; contudo, foi possível observar presença de massa de bolo alimentar compactado, com características de ração concentrada. Iniciou-se, então, um tratamento através da utilização de sonda nasogástrica e utilização de água morna, além de massagem na região esofágica até total desobstrução do esôfago. Após a manobra, realizou-se novamente outra gastroscopia, na qual o esôfago foi completamente visualizado e encontrava-se desobstruído. No estômago foi visualizado apenas presença de grande quantidade de líquido. Durante a endoscopia também foi possível observar presença de secreção purulenta na traqueia e no septo nasal. 0 tratamento ainda consistiu de meloxicam $(0,6 \mathrm{mg} / \mathrm{kg}$, 24/24h, intramuscular, durante três dias) e 2 litros de solução fisiológica acrescidos de 20 ml de lidocaína a 2\%, sem vasoconstritor. Para tratamento do quadro respiratório foi instituído sulfametoxazol (20 mg/ $\mathrm{kg}$, intramuscular, durante trê dias) e sessões de nebulização com óleo canforado associado a cloridrato de bromexina. Desta maneira, é de grande importância um atendimento precoce, já que a obstrução esofágica 
se trata de uma emergência. Com diagnóstico e tratamento imediatos, aumentam as chances de recuperação do animal, sem precisar submetê-lo a procedimento cirúrgico.

Palavras-chave: Gastroscopia. Regurgitação. Sonda nasogástrica. 